\title{
Interactivity between protégés and scientists in an electronic mentoring program
}

\author{
CARA BONNETT ${ }^{1}$, BARBARA M. WILDEMUTH ${ }^{1, *} \&$ DIANE H. \\ SONNENWALD ${ }^{2}$ \\ ${ }^{1}$ School of Information and Library Science, University of North Carolina at Chapel \\ Hill, Chapel Hill, NC, 27599-3360, USA, ${ }^{2}$ Swedish School of Library and Information \\ Science, Göteborg University and University College of Borås, Allégatan 1, Borås, \\ 501 90, Sweden (*Author for correspondence, e-mail: wildem@ils.unc.edu)
}

Received: 23 April 2004; accepted: 17 October 2005

\begin{abstract}
Interactivity is defined by Henri (1992) as a three-step process involving communication of information, a response to this information, and a reply to that first response. It is a key dimension of computer-mediated communication, particularly in the one-on-one communication involved in an electronic mentoring program. This report analyzes the interactivity between pairs of corporate research scientists (mentors) and university biology students (protégés) during two consecutive implementations of an electronic mentoring program. The frequency and structure of the interactions within each pair were examined to provide context: 542 messages were posted among the 20 mentors and 20 protégés. These messages were formed into $5-10$ threads per pair, with 3-4 messages per thread, indicating a high level of interactivity (there were more responses posted than independent messages). Mentor-protégé pairs rated as effective by both mentors and protégés posted more messages overall, had well-structured threads, had protégé and mentor postings that were similar in topic coverage and message length, and had little overt "management" behavior by mentors. However, there appears to be no clear recipe for successful interaction. Not only are there a variety of factors at play in developing an online relationship in this context, but mentor-protégé pairs can falter at various stages in the process and in various ways.
\end{abstract}

Keywords: computer-mediated communication, computer-supported collaborative learning, electronic mentoring, instructional technology, social interaction

\section{Introduction}

Mentoring has long been recognized as an effective process to help students and young professionals grow and develop new skills and attitudes, and it is practiced today in both educational and corporate settings. However, time and distance constraints can prevent the development of mentoring relationships, as is the case for undergraduate and graduate science students in rural and lower socioeconomic 
areas, who rarely have the opportunity to interact with scientists face-to-face. Most corporate and university research scientists are concentrated at research facilities and rarely have the leisure to travel to rural and lower socioeconomic colleges and universities to interact with students there. If such contact were possible, students would be exposed to a much wider range of perspectives on scientific and professional issues. Such exposure would increase the likelihood that they would envision themselves undertaking a career in scientific research.

Electronic mentoring, sometimes called e-mentoring or telementoring, involves the use of asynchronous and synchronous information and communications technology (such as electronic mail or computer conferencing) to support interaction between participants, allowing them to interact across geographical distances with fewer scheduling constraints. Furthermore, e-mail and similar text-based communication can blend the informality of conversation with the benefits of written correspondence, encouraging reflection and providing an enduring record of the exchange.

An electronic mentoring program is one way to at least partially overcome the distance between science students in rural and lower socioeconomic areas and the scientists who could mentor them. However, it is not at all clear that the expected benefits of a mentoring program could be attained if that mentoring is computer-mediated. Attainment of those goals is dependent upon the quality and quantity of the interactions between mentors and their protégés.

The current study examines the interactions between corporate scientists and biology students in two lower socioeconomic rural and urban historically black ${ }^{1}$ universities as they communicated during a Web-based electronic mentoring program. In addition to being an interesting example of e-mentoring, the results deepen our understanding of interactivity during asynchronous computer-mediated communication and how interactivity relates to the effectiveness of computer-mediated mentoring relationships.

\section{Background}

Previous electronic mentoring programs are reviewed here, with particular emphasis on evaluations of those programs. In addition,

\footnotetext{
1 "In the United States, historically black colleges and universities (HBCUs) primarily serve African American students and seldom have sufficient resources or necessary infrastructure to support faculty and student research or doctoral education" (Adessa \& Sonnenwald, 2003). Historically minority universities include both historically black universities and historically Native American universities; there are 12 historically minority universities in the state of North Carolina.
} 
previous studies that have focused on interactivity during computermediated communication are reviewed.

\section{Mentoring in a new medium}

A number of large-scale electronic mentoring projects have been established, each intended for a particular audience of mentors and protégés. Several large-scale programs, e.g., the International Telementor Program established in 1995 (http://telementor.org), connect primary and secondary students with experts who assist them with coursework. Similarly, Electronic Emissary (http://emissary.ots.utexas.edu/emissary/index.html) assembles teams of students, mentors, teachers, and facilitators to collaborate via e-mail on projects proposed by teachers. Other programs - such as MentorNet (http:// www.mentornet.net/index.html); Telementoring Young Women in Science and Engineering (http://www.edc.org/CCT/telementoring/); and CyberSisters (http://www.cyber-sisters.org/) - have been targeted specifically at women. Preliminary outcomes from these programs have been largely positive, but no studies have looked closely at the amount and quality of interactions between mentors and protégés.

Most research on electronic mentoring has focused on informing the design of future programs and identifying general ingredients for success. For example, research suggests that initial training should clarify participant roles (O'Neill et al., 1996) and establish program goals and expectations (Muller, 1997). O'Neill and Gomez (1998) propose that the "purposeful orchestration" of e-mentoring programs will lead to an increase in interest-driven partnerships and a decrease in abortive and perfunctory dialogues. According to Harris et al. (1996), the development of successful e-mentoring relationships depends on: (a) frequent, regular contact; (b) active, inquiry-based and student-centered communication; and (c) "multidimensional communication utilizing intellect and emotion, balancing personal and scholastic information shared in the exchange" (Harris et al., 1996, p. 56).

In an effort to develop a more detailed understanding of mentoring discussions, a few studies have attempted to categorize the messages exchanged by mentors and students. An early study (Murfin, 1994) coded messages by tone (friendly, neutral, or unfriendly), content (science, no science mentioned), and type (managerial/administrative, career-related, or personal). The number of personal messages showed a steady increase over time, the number of managerial messages 
(i.e., messages used to coordinate or manage the communication process itself) decreased somewhat over time, and the number of career-related messages did not change. Message tone changed over time, becoming less neutral and more friendly.

O'Neill (1998) suggests that diversity in the types of assistance and support provided may itself be the defining characteristic of electronic mentoring. Two studies have attempted to better define this diversity by categorizing messages in terms of functions or strategies employed by participants. Harris and Jones (1999) identified 21 such functions in three basic classes ("reporting information," "requesting information," and "other"), but noted that a single message typically performed more than one perceived function. Similarly, Tsikalas et al. (2000) identified about 30 strategies/functions exercised by students, mentors, and teachers in creating and maintaining project-based online mentoring relationships. They differentiated between "process" strategies, which made "explicit the phases of purpose, tone, or intensity that a conversation is expected to move through over time" (Tsikalas et al., 2000, p. 4) and community-building functions, which promoted a shared sense of purpose and the benefits of participation. They concluded that it is important to expand mentors' conceptions of their own roles and functions; and that students who were aware of their own needs for specific kinds of assistance and support, and who were proactive in seeking this assistance, had more successful e-mentoring relationships.

Bennett et al. (1998) surveyed participants to find out which topics they had discussed online as part of the Telementoring project, aimed at connecting high school girls with women in science and technology related fields. The study found that topics falling under the headings of "college" and "career" dominated the exchanges (e.g., college life and college courses or career opportunities and the mentor's career), closely followed by "personal issues" (e.g., confidence, time management, and balancing family and work). Frequently personal interests unrelated to science were used as a springboard for discussing science.

Interestingly, the researchers noticed a difference between mentors' and students' perceptions of their conversations. Many mentors reported that they did not feel they had provided any guidance because they communicated only minimally with their protégés or they believed they had not explored any substantive issues. Mentors expected more specific career-oriented conversations, and "what might have been regarded as casual chat by mentors was viewed as meaningful exchanges for students" (Bennett et al., 1998, p. 17). These 
findings are similar to conclusions drawn in a study (Young \& Perrewé, 2000) of traditional, face-to-face mentoring: mentors valued career-related behaviors exhibited by protégés, while protégés placed more emphasis on social behaviors exhibited by mentors.

Thus, research on electronic mentoring has identified key factors in fostering successful interactions between protégés and mentors. These factors include message frequency, strategies to build relationships, and protégés' and mentors' different perspectives on discussion topics. A detailed analysis of how these factors evolve during mentoring relationships would increase our understanding of interactivity among mentors and protégés and patterns that appear to lead to successful (and less successful) mentoring experiences. Research on computermediated communication (CMC), especially in educational settings, offers some expertise and tools for gaining a deeper understanding of interactivity in this context.

\section{Interactivity in computer-mediated communication (CMC)}

CMC has been found to both enhance and inhibit interaction. Because CMC lacks much of the richness of face-to-face interaction (body language, tone of voice, facial expressions, etc.), some studies conclude that CMC fosters impersonal interaction. Walther and Burgoon (1992) cite the removal of visual communication cues as a particular disadvantage, because nonverbal behavior generally carries relational information. In an educational setting, students may detect less individuality in others if the teacher/moderator is unable to create a sense of "social presence," for example, through the use of "emotions" or humor (Tu, 2000).

Conversational cohesion also can deteriorate in CMC. Interactive exchanges in a variety of CMC modes tend to be more disjointed than in face-to-face conversation. With e-mail in particular, responses often are separated from the messages to which they are responding, disrupting interaction coherence; and topics tend to decay quickly, which can create confusion (Herring, 1999). Overall, e-mail messages do not seem to be as useful as phone calls or face-to-face meetings for developing and sustaining strong social relationships (Cummings et al., 2002).

However, CMC also offers unique advantages. Students using information and communications technology in educational settings express individual opinions with less fear of interruption (Cooper \& Selfe, 1990) and office workers using CMC tend to ignore socially 
constructed cues of class, race, and gender (Sproull \& Kiesler, 1993). In addition, the online environment permits anyone to become an information provider for others, enabling students to take on a teaching role (Harasim, 1996).

While online interaction may begin as impersonal, Walther and Burgoon (1992) note that computer-mediated groups develop and evolve in relationally positive directions; indeed, Walther (1996) acknowledges the potential for "hyperpersonal communication," forms of computer-mediated contact that exceed the depth of interaction that can be achieved face-to-face. Walther (1996) concludes that people using $\mathrm{CMC}$ strive to develop similar social relationships to those found in face-to-face settings, but such relationships take longer to establish electronically. Yates (1996) notes that CMC is affected by the numerous social facets that surround and define the communication and advocates the study of specific social and cultural settings.

A variety of studies have explored interactivity as a key to understanding and evaluating CMC's effectiveness. Henri (1992) defines interactivity as a three-step process involving communication of information, a response to this information, and a reply to that first response. The presence or absence of these three-part chains of communications is an indicator of the degree of interactivity within a particular computer-mediated forum. Hara et al. (2000) used this categorization scheme to analyze electronic discourse in an online class discussion, visually representing the message interactions (HowellRichardson \& Mellar, 1996). Yacci (2000) defines interactivity in a similar fashion, as a message loop between participants. He identified message duration and lag time of response as key variables of interest and noted that the exchange of mutually coherent messages results in two outputs: content learning and affective benefits. Condon and Cech (1996) applied a similar understanding of interactivity in their study of decision-making interactions between pairs. Utterances (i.e., individual clauses) were coded into three categories: moves (e.g., suggesting an action or requesting information), responses (e.g., agreeing, disagreeing, or complying with a request), and other (e.g., metalanguage, personal information, or jokes). In particular, the moves imply a response, which may then imply another response from the initiator of the conversation.

Rafaeli and Sudweeks' (1997) work goes a step further, contrasting interactive messages with purely reactive messages. They define interactivity as the dependence among messages in threads, the extent to 
which messages in a sequence relate to each other, and the extent to which later messages recount the relatedness of earlier messages. They concluded that messages categorized as interactive are more likely to contain agreement than disagreement, are significantly more humorous, and are more likely to contain personalizing content, in the form of self disclosure or an admission. One of the most useful frameworks was developed by Zhu (1998), who analyzed electronic discussion in a distance-learning course, categorizing interaction as vertical (with some participants concentrating on others' answers rather than contributing their own) or horizontal (with more equal participation). Participants typically began as wanderers (who seemed lost in the discussion and were floundering) or seekers (who recognized their own information deficit and need to gain more information), then became contributors and mentors. Other studies have focused on the messages themselves: their structure, purpose/function and/or content. Herring (1996) analyzed electronic messages in terms of their internal structure and identified two related structures: a generalized structure (including an opening epistolary convention, a link to previous discourse, a contentful message, a link to following discourse, and a closing epistolary convention) and an electronic message structure (including a link to an earlier message, an expression of views, and an appeal to other participants). Pena-Shaff and Nicholls (2004) focused on message purpose/function. They studied knowledge construction by learners using an electronic bulletin board system, and identified eleven categories of statements within the students' postings. The most frequently used categories were clarification statements (44\%) and interpretation statements (15\%). Henri (1992) focused more on message content, proposing a theoretical framework based on five dimensions of the learning process. Messages were divided into "units of meaning," which then were categorized in each dimension. Of key interest for the current study is the interactive dimension, which was broken down into three categories: explicit interaction (a direct response or commentary to a previous idea), implicit interaction (statements that responded to a previous comment without directly referring to it), and independent statement (statements related to the subject under discussion that were neither answers nor commentary). Hara et al. (2000) sought to identify "social cues" within messages and to differentiate between surface-level cognitive processing and deeper processing. However, they noted the difficulty of coding and concluded that a reliable instrument for content analysis of CMC has yet to be developed. 
Interestingly, many of these approaches - as well as some of the strategies discussed in e-mentoring research - echo the categories developed as part of Bales' interaction process analysis. Bales (1950) proposed that the success of a group depends on two factors: how well it can solve the tasks facing it (the task function) and how well it can keep its members satisfied with the group (integrative, or socio-emotional function). His method - which categorized interaction behavior as either social-emotional or taskoriented - has been commonly used in research on the interpersonal aspects of CMC, but the task-social dichotomy has been criticized for its rigidity and inability to account for multidimensional relational qualities (Walther, 1992).

Thus, none of the frameworks developed to date for analyzing $\mathrm{CMC}$ is without flaws. Simple categorization schemes prove too inflexible, while more complex schemes include unclear categories that often are not mutually exclusive. Nevertheless, these frameworks offer a variety of useful concepts and tools for exploring interactivity in the specific context of electronic mentoring. This study aims to develop a more detailed picture of e-mentoring interaction; specifically, it poses the following research questions:

What are the patterns of interactivity between minority college students and corporate scientists who use computer-mediated communication in an electronic mentoring program?

$\bigcirc$ How are the patterns related to participants' perceptions of the interactivity?

\section{Study methods}

An e-mentoring program was implemented in two consecutive semesters: the first at Rural University, with mentors from Company 1; the second at Urban University, with mentors from Company 2. ${ }^{2}$ Each semester, the student participants (i.e., the protégés) were members of a science course at their university. The participating courses were selected by their instructors because, in the instructors' views, the students would benefit from being mentored by research scientists. In each case, the mentoring program was supplementary to the student's coursework and participation was not taken into account in the course grading/evaluation. All participants completed pre- and post-

\footnotetext{
$\overline{2}$ Participant names, including organizational names, are pseudonyms intended to protect the confidentiality of the participants.
} 
program questionnaires and interviews. Transaction logs of all Webbased interactions were also collected.

The analysis of interactivity reported here was part of a larger research project that included an overall evaluation of the e-mentoring experience (Wildemuth et al., 2001) as well as examination of participants' information-seeking processes and the program's effect on students' information horizons (Sonnenwald et al., 2001). The research methods used to examine interactivity between protégés and mentors are described in detail below.

\section{Participants}

The first implementation of the e-mentoring program (Fall, 1999) included 11 protégés and nine mentors (Table 1), forming 11 pairs (two of the scientists mentored two students each). The participating Rural University students were junior and senior biology majors enrolled in an advanced undergraduate course titled "Frontiers in Molecular Biology." All of the students in the class were offered the opportunity to participate in the e-mentoring program, and all agreed to participate in the program and the research. Rural University enrolls about 1900 students; $75 \%$ are African-American, and more than $30 \%$ come from its home county or adjacent counties. The students participating in the e-mentoring program had access to the Web via the department's

Table 1. General characteristics of study participants (Wildemuth et al., 2001)

\begin{tabular}{|c|c|c|c|c|}
\hline & \multicolumn{2}{|l|}{ Fall 1999} & \multicolumn{2}{|l|}{ Spring 2000} \\
\hline & $\begin{array}{l}\text { Rural Univ } \\
\text { protégés }\end{array}$ & $\begin{array}{l}\text { Company } 1 \\
\text { mentors }\end{array}$ & $\begin{array}{l}\text { Urban Univ } \\
\text { protégés }\end{array}$ & $\begin{array}{l}\text { Company } 2 \\
\text { mentors }\end{array}$ \\
\hline Number of participants & 11 & 9 & 9 & 11 \\
\hline Average age (years) & 20.9 & 43.4 & 25.3 & 36.6 \\
\hline Range in ages & $19-23$ & $32-56$ & $21-33$ & $26-49$ \\
\hline \multicolumn{5}{|l|}{$\operatorname{Sex}$} \\
\hline Female & 9 & 2 & 7 & 9 \\
\hline Male & 2 & 7 & 2 & 2 \\
\hline \multicolumn{5}{|l|}{ Race } \\
\hline White & & 9 & & 9 \\
\hline Asian/ Pacific Islander & & & & 2 \\
\hline African-American/Black & 10 & & 9 & \\
\hline African-American/Black, White & 1 & & & \\
\hline
\end{tabular}


computer lab, other labs on campus, and, in some cases, home computers. The mentors were biologists and chemists at Company 1 , a subsidiary of an international health-care products and services firm that had approximately 1000 employees. The mentors worked in research and development as research scientists, product developers or managers. All had Ph.D. degrees and were recommended as mentors by their management. They all had desktop access to the Web at their workplaces and some had home access to the Web.

The second implementation (Spring, 2000) included nine protégés and 11 mentors (see Table 1). The protégés were first- and second-year master's degree biology students at Urban University, enrolled in a course titled "Advanced Genetics Biology." All of the students in the class were offered the opportunity to participate in the e-mentoring program, and all agreed to participate in the program and the research. Urban University enrolls about 5600 students, $82 \%$ of whom are African-American. The students participating in the e-mentoring program had access to the Web via the computers in the professor's lab space, other computer labs on campus, and, in some cases, home computers. The Urban University student protégés were paired with mentors from Company 2, a large, international research-based pharmaceutical and health-care company (two of the students were assigned two mentors each). At the time of the e-mentoring program, the company had approximately 16,000 staff involved in biological and pharmaceutical $\mathrm{R} \& \mathrm{D}$ activities, at more than 20 sites worldwide. The mentors were employees from several divisions in the United States and United Kingdom; they had bachelor's, master's and Ph.D. degrees in a variety of fields including microbiology, molecular biology, genetics, biochemistry, and training and development. They worked as lab technicians, research scientists, product developers and managers. They all had desktop access to the Web at their workplaces and some had home access to the Web.

\section{The e-mentoring program}

Prior to the beginning of the semester, each participant filled out a profile questionnaire, which was used to match students and scientists, in consultation with the course instructor and company liaison. A structured "kickoff" event was held, involving all participants in synchronous Web-based interactions, enabling them to be introduced to each other and to become familiar with the software. 
During the program, participants interacted using $\mathrm{WebCT}^{\mathrm{TM}}$, a Web-based distance education application package, with extensive customization to meet the project's needs (Webster et al., 2000). Each mentor/protégé pair had a private discussion forum (containing threaded, archived messages), and each participant had a private forum with the facilitators where administrative or technical concerns could be aired. In addition, each participant group had its own forum: Mentors Only, Students Only, Faculty \& Mentors Only, and Faculty $\&$ Students Only. During the spring semester, some protégés and mentors were located in the same geographic area, and they also talked on the phone and, in one case, met face-to-face.

\section{Data collection during the program}

Before the program began, each participant was interviewed and asked to fill out a questionnaire concerning his or her expectations for the program. At the end of the semester, all participants again were interviewed and completed questionnaires about their experiences. The interview schedules and questionnaires are included in the appendices of Wildemuth et al. (2001).

The protégé post-program questionnaire included items concerning academic standing and attitudes toward school, expectations of the e-mentoring program, level of technology expertise and use, information use, and demographic data. The mentor questionnaire was parallel, except that it did not include the questions about academic standing and attitudes. Only the items on participant satisfaction with the quality of the mentor-protégé match are included in the current analysis; they were originally developed for the International (formerly Hewlett-Packard) Telementor Program Evaluation (http:// www.telementor.org/index.cfm).

Each participant was also interviewed before and after the program; portions of the post-program interviews were analyzed for the current study. The interviews were conducted individually by members of the research team. Participants were asked about the outcomes, both positive and negative, of their participation in the mentoring program, and asked to characterize their mentors/students and the mentoring relationships. Audiotapes of the interviews were transcribed and the comments related to the quality or amount of mentor-protége interaction are included in this analysis.

During each semester, all messages posted to all the forums were collected and archived for later analysis. These archives, or logs, included the name of the person posting the message, the date and 
time at which it was posted, a subject line, and the text of the message. Only the private forums for the mentor-protégé pairs were included in the analysis reported here, since the interactivity between mentors and protégés, and the effects of interactivity on the success of the mentoring relationship, are the primary research questions.

\section{Data analysis}

This paper primarily analyzes data from the message archives, as described above. Descriptive statistics, including the frequency of posting by each participant, the number of threads, average thread length, and average message length, were examined. These quantitative results provide an overview of the amount of interaction between mentors and protégés and, so, set the context for more in-depth analysis of the interactivity of these relationships.

In the software used for the e-mentoring program, messages were connected via threads. A thread is a set of messages bound together by the fact that one message is a response to a previous message, analogous to turn-taking in conversations. The interpretation of a message as a "response" may be based on two different actions. First, the sender of the response may use the software-based reply function (i.e., the sender clicks on the reply button to post the message). This type of response may or may not be related to the content of the message to which the reply is being sent. For example, you may reply to an e-mail from a colleague informing you of an upcoming seminar by asking that colleague if he is available for lunch that day. Second, a response may be interpreted as a response based on the content of the message (i.e., the content of the message quotes or otherwise responds to content in a previous message). For example, your colleague may send you an e-mail message inviting you to speak in her class, and you accept the invitation by initiating a new e-mail message, rather than using the e-mail software's "reply" function. The threads in the e-mentoring forums were analyzed using each of these two interpretations, since it is likely that they would differ. Specifically, the interactivity of each forum was investigated by coding each message as an independent statement or a response (explicit or implicit), as defined by Henri (1992):

- Independent statement: a posting that initiates a thread. It does not explicitly or implicitly respond to any previous message.

- Explicit response: a posting that is directly linked to a previous message. There are two categories of explicit responses. One 
category contains messages that are directly linked to a previous message because the message was sent using the software's reply function. The second category is those messages that are directly linked to a previous message because the content of the message explicitly refers to a previous message, e.g., contains quotes from it. The second category provides a content-based analysis; the first a software function-based analysis.

- Implicit response: a posting that implicitly refers to another person or message and was not posted with the software's reply function.

A simple message map (Hara et al., 2000; Pena-Shaff \& Nicholls, 2004) was also created to graphically represent the interactivity within each mentor-protegé forum.

In addition to the analysis of interactivity across all the mentorprotegé forums, five protégé-mentor pairs were selected for in-depth qualitative analysis. A key factor in selecting these pairs was each participant's self-assessment of the quality of the match as reported in the post-program questionnaire, compared to his or her respective peer group. All program participants reported that the quality of their match was at least "neutral" (3) on a 5-point scale ranging from "very poor" to "excellent" (Wildemuth et al., 2001). The two pairs identified as successful had an average rating of 4.5 out of 5 , while the three pairs identified as unsuccessful had an average rating of 3.2.

To differentiate between pairs with similar ratings, factors identified in previous research were used as final selection criteria. Our goal was to maximize the variability on each factor, in particular:

- overall participation, as measured by frequency of messages per forum, the number of threads per forum, and the number of messages in the longest thread; and

- the patterns in topics discussed in the forum, specifically the presence (or absence) of four particular topics (academic, science, career and social/interpersonal) and the co-occurrence of certain of those topics with other topics (see Bonnett (2002) for a more detailed explanation).

In this way, two pairs - one from each semester - were chosen as examples of "successful" forums. Three pairs - one from the first semester and two from the second semester - were chosen as examples of less successful forums.

The discussions between these selected mentor-protégé pairs were analyzed in greater detail to identify particular themes within and 
across pairs, with the message used as the basic unit of analysis. The first phase of analysis required a detailed content analysis of the messages. This content analysis was conducted in three steps: frequently used words were identified; those words were classified into four categories, as either academic, science-related, career-related, or social/ interpersonal; and coding reliability was checked. ${ }^{3}$ The next step in the analysis was to identify the most frequently used words in each of the four categories. ${ }^{4}$ All occurrences of those terms were then highlighted in each of the discussion forums using a different color for each category. The resulting color mappings were then reviewed to identify patterns among them. For instance, forums were analyzed to determine how career- and science-related topics were integrated into the overall discussion. In addition, the forums were examined for topics that were missing from each discussion. Throughout the process, messages or exchanges representing major themes were noted. Once an initial list of themes was identified, the forums were reviewed again to locate any conflicting or disconfirming evidence.

\section{Results: Interactivity among mentors and protégés}

To provide a context for our examination of the interactivity in the mentor-protégé forums, a summary of the activity in these forums is first presented. This is followed by a report of the interactivity within the forums and participants' view on the interactivity of the forums.

\section{Quantity of e-mentoring interactions among mentors and protégés}

As shown in Table 2, there was considerably more activity in the Spring 2000 forums (Urban University, Company 2: 384 total messages exchanged within the pairs) than the Fall 1999 forums (Rural University, Company 1: 158 total messages).

On average, Company 1 mentors sent 7.0 messages to each of their Rural University protégés, and Rural University protégés sent 7.0

\footnotetext{
${ }^{3}$ Two raters independently coded each of 990 terms. The coding was in complete agreement for 680 terms $(69 \%)$; the remaining discrepancies were resolved as described in Bonnett (2002), Appendix A.

${ }^{4}$ Only the 20 most frequently used words in each category were used to continue the analysis. The most-frequently used and least-frequently used words that were included in this analysis were: schools (196 uses) and professors (19 uses) in the academic category; genes/genetics (152) and biochemistry (12) in the science category; work/working (367) and staff (6) in the career category; and hope (175) and husband (38) in the social/interpersonal category.
} 
Table 2. Messages posted among mentors and protégés

\begin{tabular}{lll}
\hline & Rural University, & Urban University, \\
Company 1, Fall 1999 & Company 2, Spring 2000 \\
\hline Mentor to protégés & 80 & 214 \\
Protégé to mentor & 78 & 170 \\
Total & 158 & 384 \\
\hline
\end{tabular}

messages to each of their mentors. At Urban University/Company 2, mentors, on average, sent 19.5 messages to each of their protégés and protégés sent 15.5 messages to each of their mentors. Also at Urban University, two mentor-protégé pairs continued their correspondence on the Web-based discussion forum after the program's formal cutoff date. One pair exchanged 22 messages and the other exchanged 35 messages after the program formally ended.

Mentors tended to send longer messages than did the protégés; the mentors' messages were over 65 words longer, on average. In Fall 1999, the mean message length for mentors was 171 words and 100 words for protégés. In Spring 2000, the mean message length for mentors was 161 words and was 96 words for protégés. Thus, the differences in corporate settings between the mentors and differences between the university settings and student status among the protégés did not appear to influence message length.

The message posting activity by mentors and protégés was not evenly distributed over the course of each semester. Figure 1 illustrates the total number of messages per day posted by students and

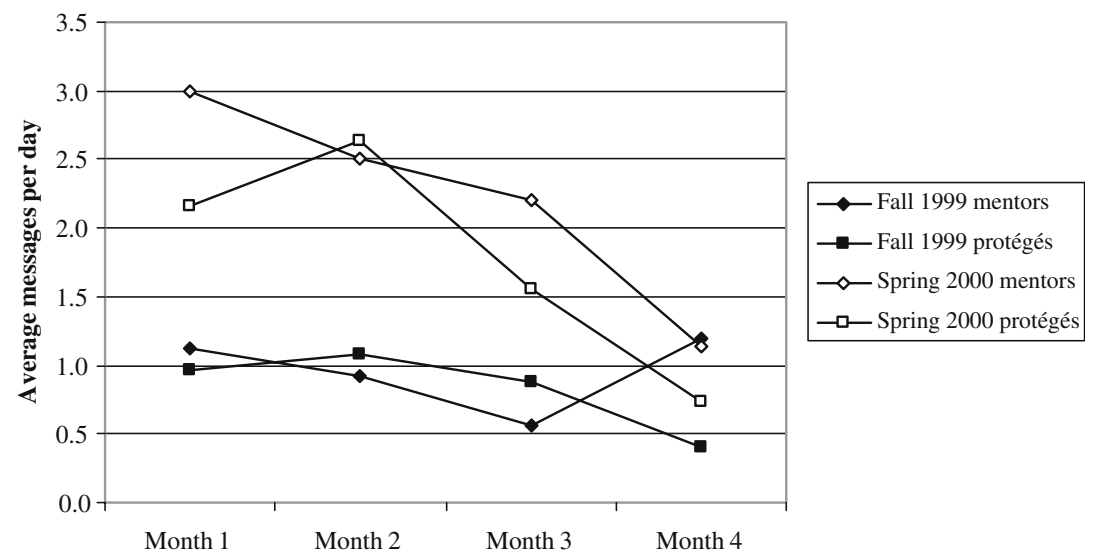

Figure 1. Average number of messages posted per day, by protégés and mentors. 
mentors, over the course of the four-month program. ${ }^{5}$ The general decrease in number of postings resembles the findings of Harris and Jones (1999), though in their study of the Electronic Emissary Project in spring 1993, the peak activity was in the second month of the semester (as was experienced by the Spring 2000 protégés).

During the first month, mentors in Company 2 posted more messages than the students at Urban University. Perhaps in response to the high number of messages sent by mentors and lower number of messages sent by protégés, protégés and mentors reversed their activity levels during the second month. Both mentors and protégés reached similar activity levels in the second month.

During the first month, protégés at Rural University (Fall 1999) posted slightly more messages than their mentors. Company 1 did not have mentoring as part of their organizational culture, and the mentors were volunteered by their management for participation in the e-mentoring program. This may account for the initial lower number of messages. During the last month, the mentors increased their posting rate, possibly in response to the protégés' higher posting rates.

Throughout the program, there was more activity in Spring 2000 than in Fall 1999. This result is probably influenced by the mentoring culture at Company 2. Study participants at Company 2 reported that mentoring and community service are integral parts of their work life; the company provides courses on mentoring for mentors and protégés, and mentoring is a valid weekly activity reported on progress reports. A second possible influence is the age and academic experience of protégés in the Spring 2000 program. As graduate students, they have more life experience and academic experience, and this experience may influence their willingness to and confidence in interacting with corporate scientists.

\section{Interactivity within the protégé-mentor forums}

In order to understand the interactivity among the protégés and mentors, it is necessary to examine the individual threads within each mentor-protégé forum, or pair (Table 3). We first investigated interactivity by examining the contrast between interactivity based on the software's reply function and that based on the explicit message content.

The analysis based on the software's reply function found more threads per forum/pair, with the average thread length being some-

\footnotetext{
5 The average was standardized by the number of days in each month, including weekend days but excluding school holidays.
} 
Table 3. Activity in forums for mentor-protégé pairs

\begin{tabular}{|c|c|c|c|c|}
\hline & \multicolumn{2}{|c|}{$\begin{array}{l}\text { Analysis based } \\
\text { on software } \\
\text { reply function }\end{array}$} & \multicolumn{2}{|c|}{$\begin{array}{l}\text { Explicit } \\
\text { content-based } \\
\text { analysis }\end{array}$} \\
\hline & $\begin{array}{l}\text { Fall } \\
1999\end{array}$ & $\begin{array}{l}\text { Spring } \\
2000\end{array}$ & $\begin{array}{l}\text { Fall } \\
1999\end{array}$ & $\begin{array}{l}\text { Spring } \\
2000\end{array}$ \\
\hline Average number of messages per forum/pair & 14.0 & 34.9 & 14.0 & 34.9 \\
\hline Average number of threads per forum/pair & 7.3 & 10.0 & 4.5 & 9.5 \\
\hline Average number of messages per thread & 1.9 & 3.5 & 3.1 & 3.7 \\
\hline Longest thread, overall & 7 & 16 & 10 & 16 \\
\hline Average number of single-message threads & 3.2 & 3.0 & 1.2 & 3.2 \\
\hline
\end{tabular}

what less for both semesters. This result would indicate that there were instances where the protégé or mentor could have appropriately used the reply functionality of the software, but did not (i.e., the content indicated that a message was a response to a previous message, even though the software's reply function was not used to post it). During Fall 1999, there were more single-message threads based on the software's functionality than there were when the analysis was based on the message content, as would be expected from the previous analysis. In Spring 2000, this order was reversed: there were slightly more single-message threads in the content-based analysis. This indicates that some of the participants in the second semester used the software's reply function even to introduce new discussion topics.

Based on the assumption that the content-based analysis is a more valid representation of participants' actual interactions, it will be used to compare the results from the two semesters. Overall, there were more messages per forum (as described above), there were more threads per forum, and message threads tended to be longer in Spring 2000 (Urban University, Company 2). Even so, there were more single-message threads in the Spring 2000 forums, as well. It would appear that, in the spring semester, some initial postings generated long dialogues and others did not generate any response, while in the fall semester, more postings generated a small amount of dialogue.

The interactivity maps in Figures 2 and 3, typical of those generated in each semester, illustrate this contrast. Figure 2 illustrates the Fall 1999 forum for Dawn Kearns (protégé) and Dave Logan (mentor). While it contains one long thread, it contains many short threads and only one single-message thread. Figure 3 illustrates one of the Spring 2000 forums, between Simon Lewis (protégé) and Moira 


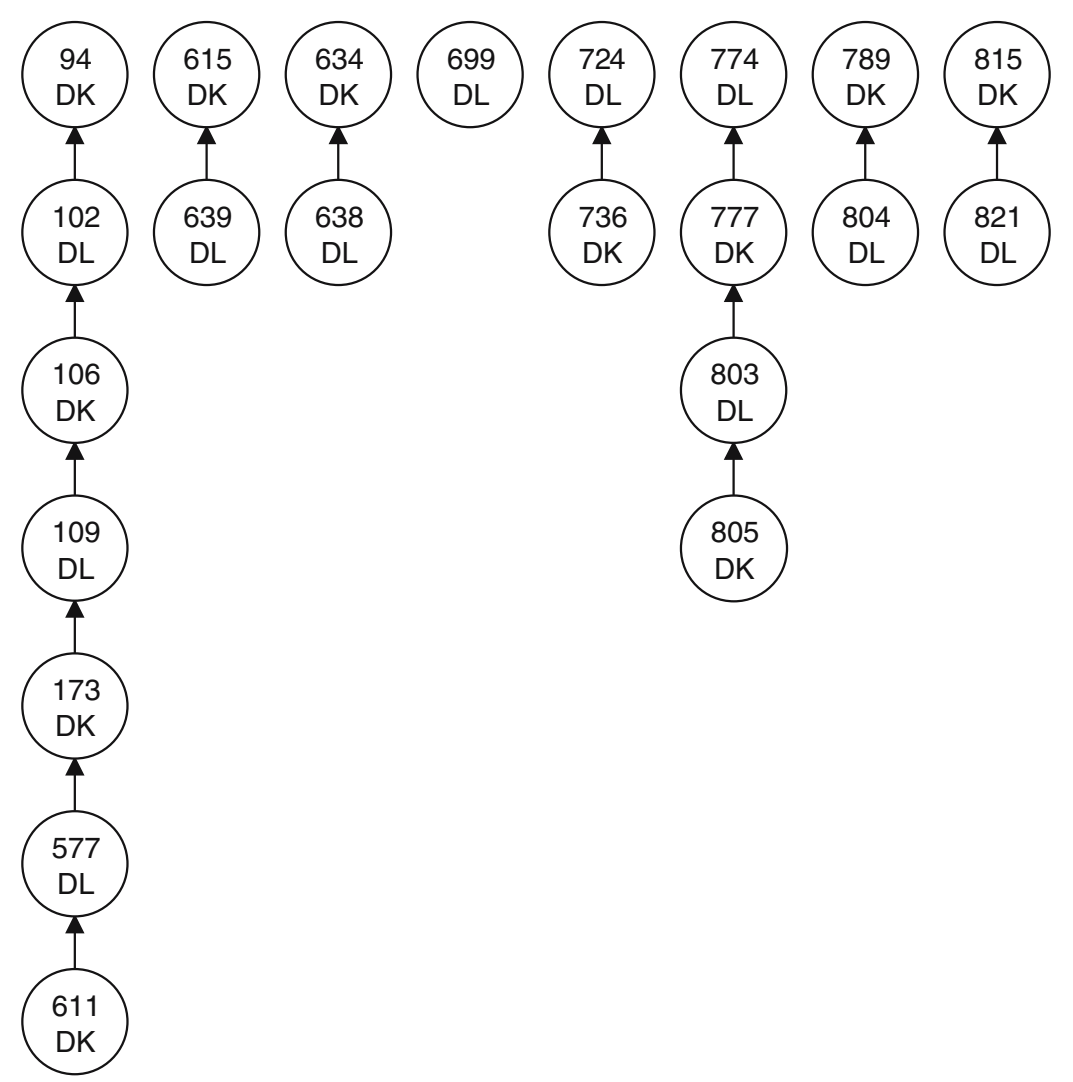

Figure 2. Sample interactivity chart, Fall 1999. Pair 1: Dawn Kearns (protégé), Dave Logan (mentor).

Thompson (mentor); it has several long threads, and also contains six single-message threads. Both pairs rated their interaction as very successful (see the discussion below), so it appears that there is no one best pattern. However, in these cases both mentors and protégés initiated and responded to threads, and this may be more important than the structure of the threads.

Further analysis of the interactivity within the forums was based on Henri's (1992) coding scheme, with each message coded as either an independent statement or a response (explicit or implicit) (Table 4). One interpretation of the data in Table 4 is to consider the independent statements as representing the initiation of new threads. In this light, this analysis would lead one to infer that the mentors' and protégés' participation was quite interactive, posting more (explicit and implicit) responses than independent statements. 


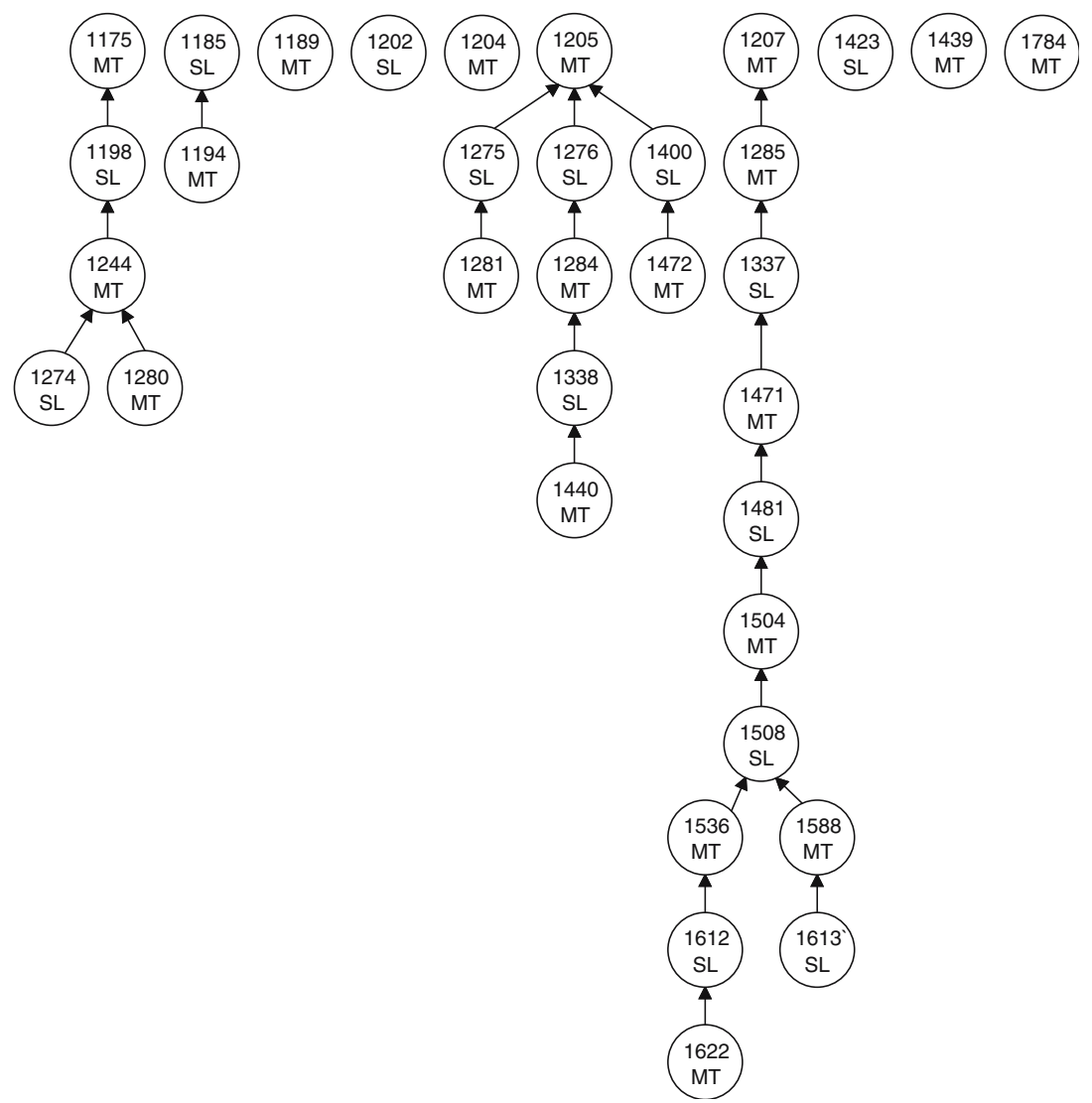

Figure 3. Sample interactivity chart, Spring 2000. Pair 2: Simon Lewis (protégé) and Moira Thompson (mentor).

Participants' views on their interactivity

During the post-semester interviews, the study participants were asked to comment on the frequency and nature of their interactions. The mentors generally responded quite positively to the experience. Five Company 1 mentors and four Company 2 mentors said they enjoyed interacting with protégés. They explained:

Marnie Waldheim: To get on there and see a message from [my protégé] Sal[ly]. That was really neat.

Muriel Vincent: It was fun... to chat with a student online. I don't get many opportunities to speak with students here [at my company]. So I appreciated that. 
Table 4. Types of messages posted in protégé-mentor forums, by sender

\begin{tabular}{|c|c|c|c|c|c|c|}
\hline & \multicolumn{3}{|l|}{ Fall 1999} & \multicolumn{3}{|c|}{ Spring 2000} \\
\hline & Mentors & Protégés & Total & Mentors & Protégés & Total \\
\hline \multicolumn{7}{|l|}{ Based on reply function } \\
\hline Independent statements & 32 & 48 & 80 & 77 & 34 & 111 \\
\hline Explicit responses & 45 & 29 & 74 & 137 & 136 & 273 \\
\hline \multicolumn{7}{|l|}{ Implicit responses } \\
\hline \multicolumn{7}{|l|}{ Based on content } \\
\hline Independent statements & 18 & 32 & 50 & 66 & 39 & 105 \\
\hline Explicit responses & 58 & 43 & 101 & 137 & 122 & 259 \\
\hline Implicit responses & 1 & 2 & 3 & 11 & 9 & 20 \\
\hline
\end{tabular}

However, the protégés saw the program as more of a class assignment, so only occasionally saw their interactions with their mentors as "fun."

In spite of the generally positive comments, there were various ways in which the experience did not match the expectations of some participants. The most frequent complaint voiced by all mentors and six of the protégés at Rural University was that they did not have enough interaction. Four mentors at Company 1 said there was less interaction than anticipated, either because the student did not write much or because they were too busy themselves to write. One mentor explained:

Jane Chen: I tried to write once a week, but it was hard... I mean, I had a note sitting on my computer and I would always say, "I'll do it today." And it would probably be Monday, and it would be Thursday before I would actually get a chance to look, and I would always feel guilty because she always replied that day and I never got around to rewriting until the following week. I mean I was... I figure she must have been checking every day, so I was more disappointed in myself for not writing more.

Seven mentors at Company 2 said there was less interaction than anticipated, and they felt uncomfortable with initiating most of the discussion. One mentor reported:

Mariel Vincent: I would write... and then it would be a long, long time before I would hear back...A couple of times I would write a note saying, "Hey, are you there? Are you busy? Drop me a line when you get a chance." But I really didn't want to do that every 
time because I felt henpecky. And I know [my protégé]'s busy [he's] a student, and he's working in a job, and he's got his own personal life...We were under the expectation that we'd be having a running dialogue at least weekly, and when that didn't happen, you start thinking, "Well, is it my fault? Or is it his fault?" That just feels uncomfortable. ... I'm happy to be an avenue of information, but I think the thing that I disliked the most was the feeling of responsibility, that I'm supposed to be reaching out.

Setting expectations for the frequency of interaction seems to be strongly related to success in developing the mentoring relationship (as was also suggested by O'Neill, 2001). Many study participants were satisfied with the interaction; however, when the protégés' and mentors' expectations about frequency of communication differed, one or the other was often dissatisfied with the interaction.

For some of the participants, the mismatch with expectations was related to the content, rather than the frequency, of their communication. Four of the Company 1 mentors said they did not get the type of questions or interaction they expected.

Gene Rarek: I also found it tough to be cozy with someone I basically don't know. I know the suggestion was made to engage in casual discussions about my day and things. It's hard for me to do that. I'm better off if someone says, "I'm on chapter 11 and photosynthesis is killing me."

Three of the mentors at Company 2 commented on the lack of continuity in their interactions with their students:

Megan O'Leary: I think I felt like we never had a continual conversation. We were always starting conversations. Nothing ever went anywhere.

Marnie Waldheim: She'll ask me a question, and I'll answer her. Or she'll bring up a topic, and I'll respond to it... I would like to see it develop into a discussion, and that never happens.

In summary, the study participants were reasonably satisfied with the electronic mentoring interactions over the course of a semester. However, there were some problems experienced: difficulty in establishing mutual expectations about frequency of communication, difficulty in negotiating appropriate boundaries for the content of the communications, and concerns over mandatory participation. 


\section{Results: Detailed analysis of interactivity in selected successful and unsuccessful pairs}

As noted above, five mentor-protégé pairs (two successful and three less successful) were selected for more in-depth analysis. After an overview of the interactions in these pairs is presented, a thematic analysis of the interactivity within these pairs will be provided.

\section{Overview of interactions in selected pairs}

The interactions within each of the five mentor-protégé pairs is summarized in Table 5. In Fall 1999, student Dawn Kearns and mentor Dave Logan (Pair 1) each rated the quality of the match as "good", i.e., 4 on a 5-point scale. Their exchange began with a combination of all four topics (academic, science, career and social/interpersonal) and continued with a high density of coded topic terms throughout. The forum included one long string of messages, along with several shorter strings (Figure 2). In Spring 2000, student Simon Lewis and mentor Moira Thompson (Pair 2) rated the quality of their match as "excellent," i.e., 5 on a 5-point scale. However, the structure of their exchange was somewhat different. They began with a combination of academic and social/interpersonal topics, later expanded to include science and career topics, and came full circle to close with academic and social/interpersonal topics. Their exchange included one long string of messages, several shorter strings, and several independent statements (Figure 3). It appears that social/interpersonal interaction in combination with science-oriented topics and a flexible approach to the structure of communication worked well for these pairs.

In comparison, three pairs - one from the first semester and two from the second semester - are examples of less successful interactions. In Fall 1999, student Denise Bushnell and mentor Elise Mason (Pair 3 in Table 5) rated the quality of their match as neutral and good, respectively. Their exchange began with some academic and social/interpersonal topics but primarily focused on science. It included one long string of messages and several independent statements. In Spring 2000, student Sandra Forester and mentor Milly Pavlova (Pair 4 in Table 5) each rated the quality of their match as neutral. Their exchange was dominated by career topics and included several short threads. Student Sienna Johnson and mentor Meredith Yu (Pair 5 in Table 5) also rated the quality of their match as neutral. Their exchange got off to a comparatively slow start, was dominated by social/interpersonal topics, and was characterized by much more 


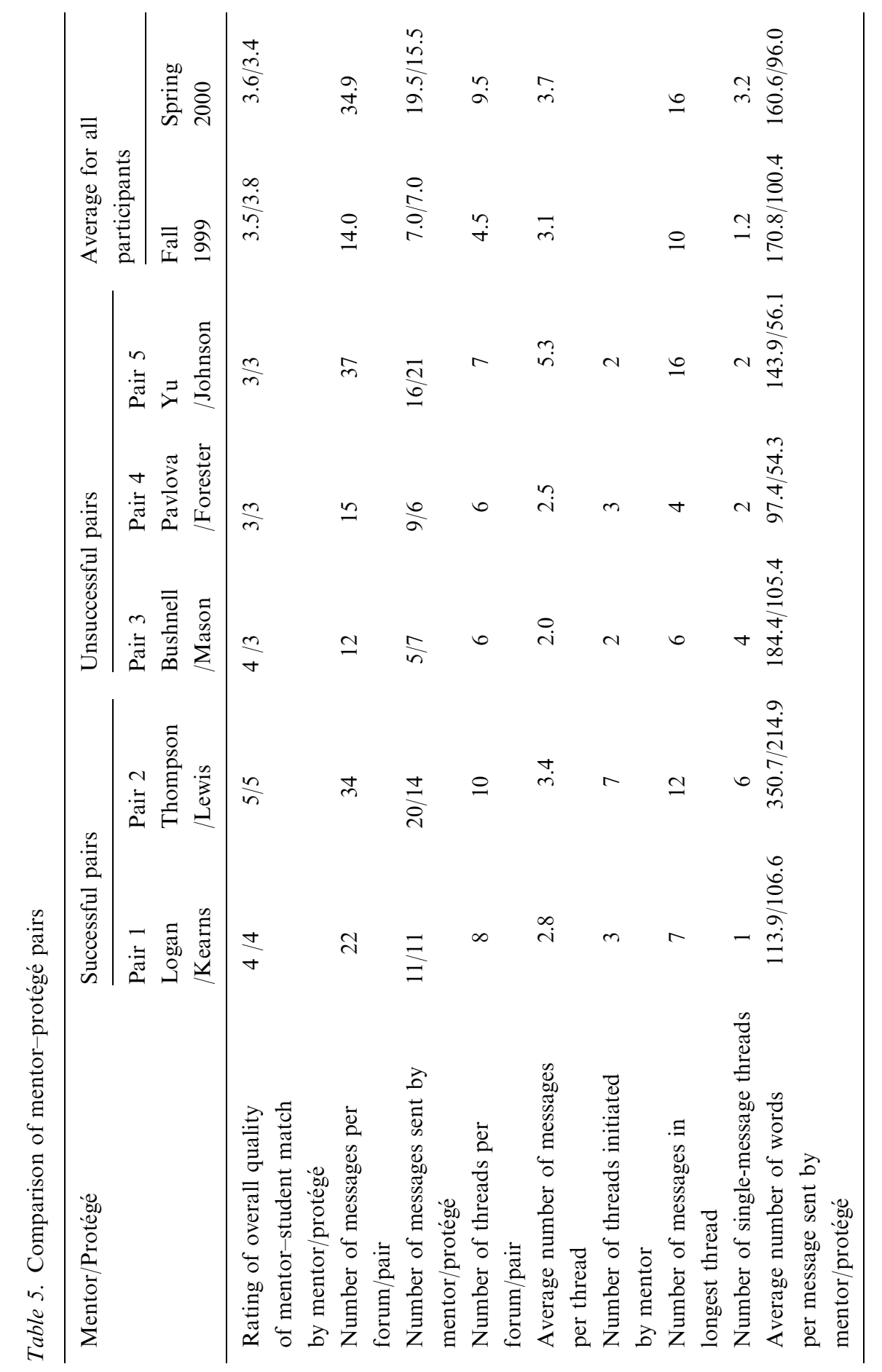


complex interactivity than most, with many strings that referred back to each other. Thus, these less successful exchanges did not contain a balance between interpersonal and science-oriented topics or a flexible structure.

Thematic analysis of interactivity in selected successful and unsuccessful pairs

\section{Usage of familiar formats}

The internal structure of many of the individual messages exchanged as part of the e-mentoring program was similar to that found by Herring (1996). Messages contained an opening epistolary convention characterized by increasing use of social/interpersonal words, a contentful message, and a closing epistolary convention, again with increasing use of social words. For example, a typical message from a protégé to a mentor (pair 2) reveals a structure similar to that of a traditional letter, with academic and career-related content sandwiched in between a social greeting and social closing:

Hi Elise, how are you? Fine, I hope. I haven't talked with you in a while, so I thought I would drop a few lines.

I am anxious to graduate. After graduation I would like to attend Virginia Commonwealth University. I am really interested in Forensic Science. They offer a Master's Program in Forensic Science and I think it will be beneficial to me. Do you have a Doctorate degree? If so, where did you get it from? Can you give me any advice about graduate school?

Well, I hope everything is going well for you and I will be waiting to hear from you. Denise ${ }^{6}$

\section{Forum structure}

Interestingly, one of the successful forums had a structure that was parallel to the structure of an individual message, with more social words used in messages at the beginning and the end of the exchange as a whole. The exchanges among Pair 3 included a high percentage of social and academic topics in the first three e-mails and the last three e-mails of the exchange, while the middle messages included more career- and science-related discussion. Studies of online communities - participants in a distance learning class, for example - show

\footnotetext{
${ }^{6}$ While the original wording and tone of all e-mail messages has been preserved, misspellings were corrected to make this report easier to read.
} 
that members exhibit behaviors that traditionally identify the presence of a community offline, such as building a common history, socially constructing rules and behaviors, and demonstrating signs of conscious disengagement from the online community when they leave (Haythornthwaite et al., 2000). This structure could indicate an effort by one or both participants to initiate the relationship and later create a sense of closure for the relationship. However, because this phenomenon was observed in only one of the five pairs, more research specifically of successful pairings - is necessary to confirm whether such a structure is common across other exchanges.

\section{Avoidance of complex interactivity structures}

Within forums, threads can develop (or be organized) in a variety of ways, such as a linear sequence, a tree structure or an acyclic network. For example, the exchange between Pair 1 is an example of a fairly simple linear structure (Figure 2), while the exchange between Pair 5 (Bonnett, 2002) was more complex, with responses referring back to other messages outside the linear path, possibly forcing the reader to remember details of previous messages or to jump between messages in different threads or linear sequences. These results suggest that a simpler structure may prove more effective in electronic exchanges because complexity may place a cognitive burden on the reader and thus hinder the flow of correspondence. More successful pairs were more likely to clearly organize their threads by content.

\section{A quick beginning with substantive content}

This study suggests that mentor-protégé pairs should not spend time working out the details of correspondence at the beginning. Successful pairs jumped into the exchange as if it were a conversation in progress, with content beyond basic social pleasantries. For example, one protégé asked her mentor in the first message which college she attended. Another protégé told her mentor in the first message that she had her first interview for graduate school in a few days and asked the mentor for advice on how to handle it. Similarly, one mentor told her protégé she had a son in college and asked how he thought parents could best support students in coping with the pressures of university life. These questions launched these pairs into an immediate discussion of substantive issues that helped them move quickly from the neutral stage of just getting to know each other to a friendlier tone of interaction.

By contrast, one of the less successful pairs had difficulty just managing to talk to one another due to technical problems: The server 
was down when both tried to log on, and these troubles prevented them from having any meaningful dialogue for quite a while. Pair 5 exchanged 15 messages focused entirely on the details of when they should talk before engaging in any content-filled discussion. As a result, the tone of those early messages was comparatively neutral, with none of the sharing of personal detail that characterized more successful pairs.

Explicit management of time lags

A positive start doesn't necessarily ensure a successful relationship overall. Time lags in responding can hurt a pair's momentum if not properly managed. The data suggest that both mentors and protégés should respond to all content in previous messages in order to minimize the negative effects of time delays in an electronic conversation. This helps to reestablish the flow of conversation after a delay.

The following exchange demonstrates a successful management approach used by Pair 1 after a six-day lag in their interaction:

Hey Doc!!!

Haven't heard from you lately. How are things going where you are? Things are okay here. I finally filled out applications to colleges in Georgia. I also requested an application to the Georgia Bureau of Investigation to work in the crime lab division. So I am just waiting to hear from people now. I did okay on my last test in Frontiers of Molecular Bio. class. I made a B. So I was happy. We have another test on Thursday and midterms on next Thursday, so if you don't hear from me in about two to three days, I am studying for midterms. I have to be on my way now, but take care of yourself and I hope to talk with you soon.

Dawn

Hi Dawn,

You probably guessed it, the last 2 weeks have been very busy for me too! I am finally getting a breather. I will respond to each of your messages - I think I am now 3 behind, including this one.

Great News on your test! That is excellent! Keep plugging away and the grades will come along for the ride. Remember that good things happen to good people.

It sounds like you are really on the ball and very career motivated. As far as colleges, have you decided on a medical/healthcare based career? It also sounds like you are expanding your options with the application to the crime lab. There really are a lot of interesting choices out there to investigate. 
Oh well, that's all for now. I wish success on your midterms and I'll talk with you soon. Cheerio,

Dave

The four-topic message as an invitation to interactivity

While this analysis confirms previous studies regarding the importance of balancing intellect and emotion in messages, it also suggests the importance of balancing specific discussion topics (in this case, academic, career, science and social/interpersonal content). A key indicator of this balance is the distribution of four-topic messages in the exchanges.

These four-topic messages need not be lengthy, as evidenced by a typical four-topic message from the protégé in Pair 2:

Hi Elise!! How are you doing? Fine, I hope. My class schedule is not too bad, but I have several meetings to attend and research to do in the cell laboratory. I am taking Frontiers in Molecular Biology, Biochemistry, Genetics, Intro. to Business, \& Biological Research. As of now I have had a genetics test (9/24), a biochemistry test (9/23) and I have a Frontiers in Molecular Biology test tomorrow.

I am not having any difficulties right now. MWF I do research in the cell biology lab and TR I work at Food Lion [a grocery store] so when I am not in any meetings I am relaxing. In my spare time I enjoy relaxing with my friends and just SLEEPING!! Well, I am getting ready to study so have a great day. Denise

While less successful pairs did not necessarily exchange fewer four-topic messages, their forums exhibited clear imbalances in the distribution of those messages. Specifically, mentors and protégés sent the same number of four-topic messages in the successful pairs (five each for Pair 1 and four each for Pair 2), while there were significant imbalances among the less successful pairs. For example, the mentor in Pair 4 sent five fourtopic messages, while the protégé sent none. The mentor in Pair 5 sent four four-topic messages while her protégé sent only two, and the mentor in Pair 2 sent one such message, while her protégé sent two.

The four-topic message allows variety and the ability to customize the conversation and, perhaps, the relationship overall. Unlike a faceto-face conversation, which often proceeds in an interactive linear fashion, participants can take a nonlinear approach, responding first to those topics that especially interest them. It introduces a social dimension, i.e., customization of a response, that might be impossible in a face-to-face setting. In the e-mentoring context, it allows mentors and protégés to discuss a variety of facets of "doing science," such as sharing new information resources including valuable Web sites. 
Invitation to interact

To perpetuate successful interaction, it appears that a four-topic message should be viewed as an invitation to interactivity and should receive a four-topic response in kind. Problems occurred in pairs that did not provide these responses. For example, the protégé in Pair 2 described her class schedule, upcoming tests and research in the cell biology lab in a four-topic message to her mentor. When the mentor did not respond, she sent a follow-up message. Finally, the mentor apologized for not answering sooner, but her message was a description of the project she was working on, with no acknowledgment of the protégé's earlier description of her own coursework. The protégé attempted to bring the conversation back:

Hi Elise, your project sounds very interesting. I love doing research and just hanging around in the lab. Most people ask me how do you stay in the lab all of the time. Well, that is what I like to do.

However, that did not lead to any more questions about the protégé's academic concerns or research; instead, her mentor responded by talking about a work presentation she did and even noted, "scientists love to talk about what they do if they have a captive audience." The conversation ended four messages later, about two weeks before the semester's end.

Content mirroring as indication of successful interaction

Not surprisingly, this analysis revealed that messages on particular topics tend to elicit responses on those topics. For example, a message from student Simon Lewis inquiring about family, career and academic topics elicited a response from his mentor, Moira Thompson, in those categories:

Simon Lewis: Hello again..... Well I also want to know how difficult is it to have time to start a family? Did you start your family while in school? Are you married? If so where did you meet your husband? Was it hard to find a location to live that both of you liked? Feel free to tell me "NONE OF YOUR BUSINESS" I won't take it personal. I just want to know how to gain the things in life that are really important and the troubles that come along with it.

Moira Thompson: I can remember before I was married at how awful I thought it was that just at the point when you were having to make decisions about family... one is also making decisions about career. Everything seemed SO important! I guess the bottom line is the 
more you can figure out what you want... the easier those decisions become. For one, I knew that I WANTED to have a husband I loved, and I WANTED to have children, and I WANTED to have a job that I liked too. So, I tried to make decisions that balanced all three. Sometimes one took precedence over another, but I never let go of each basic wish. Obviously, when you are married... decisions become harder because some decisions will become joint decisions. Others will be yours or theirs. Sometimes you don't even know whose decision it is until it's already done. I firmly believe that only you can decide what you want... so be honest with yourself and learn to realize that you ARE the decision maker for your own life. This doesn't mean that you have control of everything. That is, opportunities and temptations will be presented to you, but as an adult, you must own up to being the person making choices. And sometimes it's those "little" choices, like whether to copy a car key. They all count. Most of the decisions are actually the small ones. Another is whether to do your homework each day when you are in middle school. I'm trying to teach my eighth grader about that one! Do I sound like I'm lecturing? If so, lecture right back whenever you feel like it.

Mirroring message length

Another characteristic of successful interaction focuses on mirroring message length. Data suggests that in successful interaction, messages of a certain length tend to elicit messages of a similar length, with the mentor more likely to play a leadership role in this pattern. This pattern was especially noticeable among the two pairs who rated themselves as successful. For example, student Simon Lewis began his discussion with mentor Moira Thompson (Pair 2) by sending comparatively short messages of less than 100 words. She responded with longer messages, often longer than 200 words, and over time, his responses became correspondingly longer (Bonnett, 2002). At one point in the exchange, he even mentioned the issue of message length, writing: "I really don't have much time to reply so please forgive me if I'm too brief."

Even among pairs who did not rate themselves as successful, mirroring occurs on occasion. For example, mentor Elise Mason's longest message to her student Denise Bushnell (273 words) elicited the student's longest message in response (243 words). Unfortunately, this occurred near the end of the program, and their exchange ended soon after.

Horizontal interaction that emphasizes community building

The literature indicates that mentors should expand their conception of their own role and that protégés who know their own needs and 
seek assistance are more successful. This analysis suggests that pairs where both participants feel equally comfortable bringing up new topics and asking questions tend to rate the match more highly, while pairs in which the mentor acts as a "manager" tend to be rated as less successful. Thus, community-building functions are preferable to "process" strategies (Tsikalas et al., 2000), and horizontal interaction is preferable to vertical interaction, with the goal of moving a protégé from the seeker role into more of a contributor/mentor role in the exchange (based on Zhu's 1998 framework).

Our analysis yielded positive examples of successful horizontal interaction, as well as negative examples in which mentors acted more as teachers and managers and less as equal participants. Pair 2 offered one positive example of how mentors can invite their protégés to take on a teaching role. Rather early in the exchange, the mentor issued this specific invitation:

I would like for you to be very proactive about asking me specific questions on ANY topic. We are here to benefit each other. I think that students can mentor those who are older or further in their careers if we are willing to listen.

She immediately received a positive response from her protégé:

Hello, Moira. I guess I do have a lot of questions....let me see, let's start with your field, what do you do, why and how did you end up doing it?

However, a lack of such clear communication about roles and expectations can lead to confusion. For instance, the protégé in Pair 5 asked her mentor several questions about working in an academic setting versus industry, but when she received no immediate reply, she sent the following message:

I did not mean to ask so many questions. These are just some issues we can incorporate into our messages. I hope your day has not been too busy, but what else could it be in the sciences (smile). Sienna

On a positive note, mentors who allowed a more horizontal relationship with their protégés received benefits from doing so. For example, when one mentor shared with her protégé that there had been a death in her family, she received a comforting message in response:

Hi Elise,

How are you doing? I am sorry to hear about your grandmother, but just remember everything happens for a reason. Just take one day at 
a time and try not to stress yourself about work. I am going to Rocky Mount, NC for Thanksgiving and the day after Thanksgiving me and my mom will be heading to Williamsburg to do some shopping. Today I have a genetics test and tomorrow I have a biochemistry test. There is so much to know in biochemistry it really is stressful. Well, just thought I would respond back to you and take care of yourself.

Denise

Thus, it is important to remind mentors that they need not know all the answers or always present a strong front; indeed, revealing their situations and personalities can encourage a protégé to do the same and the mentor may benefit as well.

In contrast, students who seemed to view their mentors in a more limited role tended to ask impersonal questions that did not help in developing the relationship. For example, Sandra Forrester's exchange with her mentor (Pair 4) included comparatively little social or interpersonal discussion. Instead, Sandra seemed more comfortable asking specific scientific questions and, as a result, the pair's messages tended to sound more like impersonal memos than friendly conversation:

If you know any other enzymes which are not proteins that would be quite helpful, or just more general info on abzymes. Thank you again. Sandra

Pair 1 provided an example of how protégés and mentors can move from specific questions into a more personal, horizontal interaction:

Hi Dr. Logan

I made it through the [hurricane] okay. I guess it was after the storm that was terrible. All streets were closed going to and coming from (the city). But everything turned out rather well.

I have a question. Right now, I am looking to go into medical technology. I know I have to be certified before entering that field. But it is rather hard getting application information from hospital-based programs in North Carolina. How do I go about receiving applications and getting more information about programs that are done through and by the hospital?

Have a blessed day.

Good morning Dawn,

I'm happy to hear you weathered the storm. I have seen clips from $T V$ indicating that flooding appeared widespread and very damaging. 
I hope you weren't affected too much.

I would try a few approaches to obtaining information from hospitals about their programs. Programs may vary from place to place and I would try contacting many different places. One approach would be to see if a number of them have Websites, you might be able to screen out programs.

Another approach would be to call the hospitals directly and ask to be directed to someone who could help you. In this case you will want to be prepared to state to them exactly what you are requesting of them.

What has been your approach so far? You may want to search for hospitals on the Web outside of $N$. Carolina for literature and to get a feeling for what the requirements are.

I hope this has helped, although I recognize it is rather vague. If you can provide me a little detail on your expectations I'm sure more things will come to mind.

Have a nice Monday.

In this exchange, both participants framed the career-oriented discussion between a socially oriented greeting and a friendly, personal closing. The mentor, in particular, took care to avoid sounding abrupt in the response, inviting the protégé to ask further questions if she needed additional information. The overall tone of the exchange resembles that of a conversation between equals rather than a teacher or manager answering the question of a subordinate.

\section{Discussion}

Amount of mentor-protégé interaction

The overall quantity of interaction between mentors and protégés was reported in Tables 2 and 3. The two cohorts differed in their overall amount of communication, with more than twice as many messages posted during Spring 2000 as in Fall 1999. The most likely explanation of the overall difference in amount of student activity is the difference in the patterns of activity established in the first month of the program (Figure 1). The mentors at Company 2 led the way, averaging three messages per day during the first month. Their protégés increased their activity levels in the second month, mirroring their mentors' earlier activity. The Company 1 mentors and Rural University protégés began the program with a much lower level of activity in the first month (both groups averaging about one message per day). It seems likely that participants interpreted their partner's level of 
activity as representing his or her level of commitment to the exchange, a key relationship factor affecting one's willingness to engage in a mentoring relationship (Young \& Perrewé, 2000). For future electronic mentoring programs, the mentors, in particular, should be encouraged to post messages frequently, and it is likely that this will encourage protégés to post frequently.

One of the general questions that was not answerable at the beginning of the program concerned the level of activity that participants should be encouraged to maintain. Clearly, more activity would be better, but most participants were under some time constraints and were worried about the amount of time they might need to devote to the program. Therefore, the facilitators recommended that each participant try to post at least one message per week. During Fall 1999, there were 14 messages posted per pair (about 1 per week); during Spring 2000, there were 35 messages posted per pair (over 2 per week, or 1 per participant per week). Thus, the Spring 2000 program achieved about the level of activity that was originally recommended by the facilitators. Based on the post-semester comments from all the participants, it appears that participants prefer this level of activity.

\section{Quality of mentor-protégé interactions}

One way that the quality of mentor-protége interactions can be assessed is in their degree of interactivity. Taking an earlier (1983) definition from Bretz, Henri (1992) defines interactivity as a three-step process involving communication of information, a response to this information, and a reply to that first response. The presence or absence of these three-message chains of communications is an indicator of the degree of interactivity within a particular Web-based forum. Based on this definition, the mentor-protégé forums in both semesters were reasonably interactive. The average length of a thread in Fall 1999 was 3.1 and in Spring 2000 was 3.7 (Table 3). In both semesters, more responses were posted than were independent statements (Table 4). A closer look at the patterns of interactions that actually occurred in the mentor-protége forums (as illustrated by examples in Figures 2 and 3) indicates that the Spring 2000 forums were more interactive: threads, when they occurred, tended to be longer and more complex than the typical threads in Fall 1999. It is likely that most of this difference can be attributed to the overall difference in level of activity across the two cohorts. 
A second perspective on the mentor-protégé interactions is to examine who initiates discussions. A broad view of this aspect of the interactions can be obtained by looking at the ratio of responses to independent statements for each group in each cohort. In Fall 1999, the mentors posted 3.3 times as many responses as independent statements, while the protégés posted 1.4 times as many responses as independent statements. In Spring 2000, mentors posted 2.2 times as many responses as independent statements and the protégés posted 3.4 times as many responses as independent statements. From these data, we can conclude that, in the Fall 1999 program, the protégés initiated more of the threads, with the mentors responding. This pattern was reversed in Spring 2000, with the mentors initiating more threads and protégés responding. As the more senior member of the pair, it can be argued that the mentor should take responsibility for initiating threads of discussion. However, further qualitative analysis does not necessarily confirm this recommendation. In the pairs analyzed in detail, only one of the mentors initiated more threads than did her protégé (a successful pair, with the mentor initiating five of the eight threads); in the other four pairs, the protége initiated at least half - and often more - of the discussions. This suggests that allowing the protégé to set the discussion agenda may be a useful strategy.

In summary, the relationships between the mentors and protégés in the e-mentoring program can be characterized as reasonably interactive (with some room for improvement). The relationships that formed between the mentor-protégé pairs were on a professional level, which was more satisfactory to some participants than to others.

More in-depth qualitative analysis showed that there is no clear recipe for successful interaction; not only are there a variety of factors at play in developing an online relationship in this context, but mentor-protégé pairs can falter at various stages in the process and in various ways. Successful interaction seems to require a combination of factors, including:

- Linear structure of exchange: A linear exchange with threads organized by content is preferable to a more complex structure with responses referring back to other messages outside a linear path.

- Importance of a quick, content-filled beginning and successful management of time lags: In order to kick-start the conversation and keep that momentum going, participants should jump right in to specific content and should be sure to respond to all content in their partner's previous messages in order to minimize the negative effects of time delays. 
- Good balance of topics to stimulate interactivity: A balance of topics allows participants to customize the conversation and the relationship overall, introducing the potential for both social and task-related discussion and giving participants the choice of responding first to those topics that especially interest them.

- Mirroring content and message length: A message that includes a variety of topics is more likely to lead to a successful exchange if the receiver responds in kind, with a message addressing all the topics introduced. Problems tend to occur in pairs where one participant regularly ignores content introduced by the partner. It is important to note that either partner can take a leadership role in introducing new content; although mentors are the more senior partner in this particular context, it can be useful to allow the less senior participant to set the discussion agenda. Mirroring in message length is somewhat different: The pattern in successful pairs seems to indicate that mentors who send longer messages encourage their students to send longer messages in response, which encourages overall interactivity and builds stronger relationships.

- Limited overt "managing" by mentors: Overall, the results suggest that horizontal interaction, where both mentor and protégé interact as equal participants, is preferable to vertical interaction, where mentors act more as teachers and managers. In addition, "communitybuilding" strategies, in which mentors and protégés interact as colleagues and provide mutual support and encouragement, are preferable to "process" strategies aimed at explicitly defining specific roles, setting expectations and actively managing communication.

\section{Conclusion}

An e-mentoring program was implemented, linking corporate scientists with university biology students in two consecutive semesters, and their interactions were examined in detail. The amount of interaction varied across the mentor-student pairs, with student behavior related to message frequency and message length mimicking the behavior of their mentors. There were more messages posted in Spring 2000 than in Fall 1999. On average, the pairs sent 14 messages to each other in Fall 1999 and 35 messages to each other in Spring 2000. On average, these messages were formed into 5-10 threads per forum, with 3-4 messages per thread.

While none of the participants rated the experience negatively, some pairs rated their interactions as more successful than others. The successful pairs posted more messages overall with only brief lags 
between postings, had well-structured threads with topic coverage balanced across messages, had student and mentor postings that were similar in topic coverage and message length, and had very little overt "management" behavior by the mentors.

\section{Limitations}

The fact that the participant sample represented a small, fairly specific group limits the extent to which these findings can be generalized to other electronic mentoring contexts. For example, we do not know if the findings are influenced by the participants' discipline (natural science), organizational and institutional settings (R\&D corporations and universities in the USA), socio-economic class, ethnicity and/or gender of participants. Nonetheless, the results do offer a depth of understanding that might not be available from a broader analysis of a larger participant group. Further studies utilizing other populations should test the robustness of the findings.

Interviews conducted for this project focused on overall evaluation of the program. In future studies, we recommend that interview questions focus on specific issues of mentor-protégé interaction that emerged in this study and previous research, for example, whether participants were aware of the structure of their exchange, attempts by either participant to manage the exchange, or mirroring within the exchange.

\section{Implications for e-mentoring programs}

While the limitations of the current study must be taken into account, the results suggest ways in which future e-mentoring programs can improve the likelihood that protégés and mentors will have a positive experience. In the program studied here, it was suggested that mentors and protégés plan to exchange messages weekly. The results indicate that this suggestion be made even more strongly, to avoid time lags, generally interpreted by participants as non-responsiveness or a lack of interest by their partners. In addition, participants should be encouraged to begin their interactions with messages covering a range of topics. Mentors should also be encouraged to form horizontal relationships, treating the protégés as equal participants, rather than taking a more supervisory tone. Finally, it would be useful to provide additional training in using Web-based discussion software, particularly in relation to the use of the software's reply function to form well-defined threads of discussion. 
The e-mentoring programs studied here were embedded within the context of particular university classes. The class instructors were enthusiastic about providing this opportunity to their students and set aside some class time for the program kick-off session. However, the program was voluntary for the student participants and participation was not considered in evaluating the student's coursework. Both the instructors and the students responded positively to this model. However, while such a program may be desired by individual teachers, it is generally beyond their capabilities to establish and maintain. Course management software that is currently available needs to be customized to allow private mentor-protégé discussion, and most teachers do not have the time or the technical skills to perform this customization. Because a mentoring program would be a desirable addition to many university courses, we encourage software developers to make this functionality a standard part of future course management software.

\section{Suggestions for future research}

The current study reported on two implementations of an e-mentoring program, developed on a single Web-based platform. Future research should expand the scope of this study in two ways. First, future studies of e-mentoring programs should examine a wider range of interaction channels, to see how they interact with each other. For instance, some of the participants in these studies asked about the possibility of videoconferencing or telephone conversations. Others, particularly mentors, asked about the use of e-mail for communicating with their partners. For the current study, videoconferencing was not technically feasible and telephoning and e-mail were discouraged in order to focus our attention on Web-based discussion forums. Future studies should explore people's use of a repertoire of communication channels, to understand their interactions and how people select particular channels for particular purposes. Second, future studies should study longer-term e-mentoring programs. Each of the two implementations studied here was one semester in length. It's possible that, given more time, pairs initially less satisfied may develop stronger relationships and, thus, have a more satisfying experience. Similarly, those initially satisfied may become less satisfied over time. Longitudinal studies can help illuminate whether e-mentoring among the same mentors and protégés is sustainable over time. 


\section{Acknowledgements}

Special thanks to the students and mentors participating in the e-mentoring program described in this report, and to Gary Harmon and Goldie Byrd, instructors of the classes involved. Additional assistance as project facilitator or in data analysis was provided by Emily Brassell, Melissa Conley-Spencer, P. Brian Hilligoss, Victoria Kindon, Vikki Mercer, and Monecia Samuel. The e-mentoring program was directed by Diane H. Sonnenwald; Barbara M. Wildemuth was a co-investigator. It was funded by the Partnership for Minority Advancement in Biomolecular Sciences (W. E. Bollenbacher, director); grants from the Howard Hughes Medical Institute and Ortho Clinical Diagnostics to W. E. Bollenbacher, Department of Biology, University of North Carolina at Chapel Hill; and the School of Information and Library Science at the University of North Carolina at Chapel Hill. Partial support also was provided by the STC program of the National Science Foundation under Agreement No. CHE9876674 and North Carolina Central University. Mentor participation was supported by GlaxoWellcome, Inc. and Ortho Clinical Diagnostic Systems.

\section{References}

Adessa, C. \& Sonnenwald, D.H. (2003). Exploring collaboration among historically black universities \& doctoral/research universities in the USA. Paper presented at the UNESCO Conference on Intercultural Education, Jyväskylä, Finland, 15-18 June 2003. Available at http://www.jyu.fi/ktl/unesco2003/tiivistelma/2A-363.htm (Last accessed 16 April 2005).

Bales, R. (1950). Interaction process analysis: A method for the study of small groups. Chicago: The University of Chicago Press.

Bennett, D., Tsikalas, K., Hupert, N., Meade, T. \& Honey, M. (1998). The benefits of online mentoring for high school girls: Telementoring Young Women in Science, Engineering, and Computing Project, Year 3 Evaluation. Center for Children \& Technology Reports. Available at http://www2.edc.org/CCT/admin/publications/ report/telement_bomhsg98.pdf (Last accessed 10 July 2003).

Bonnett, C. (2002). Mirroring and managing in electronic mentoring: Factors in interactivity between student-scientist pairs. Unpublished master's paper, University of North Carolina, Chapel Hill. Available at http://ils.unc.edu/MSpapers/ 2735.pdf (Last accessed 10 July 2003).

Bretz, R. (1983). Media for interactive communication. Beverly Hills: Sage.

Condon, S. \& Cech, C. (1996). Discourse management strategies in face-to-face and computer-mediated decision making interactions. Electronic Journal of Communication/La revue électronique de communication 6(3). Available at http://www.cios. org/www/ejc/v6n396.htm (Last accessed 10 July 2003). 
Cooper, M. \& Selfe, C. (1990). Computer conferences and learning: Authority, resistance, and internally persuasive discourse. College English 52(8): 847-869.

Cummings, J.N., Butler, B. \& Kraut, R. (2002). The quality of online social relationships. Communications of the ACM 45(7): 103-108.

Hara, N., Bonk, C.J. \& Angeli, C. (2000). Content analysis of online discussion in an applied educational psychology course. Instructional Science 28: 115-152.

Harasim, L. (1996). Online education: The future. In T.M. Harrison \& T. Stephen, eds, Computer networking and scholarly communication in the 21st-century university, pp. 203-214. State University of New York Press: New York.

Harris, J., O'Bryan, E. \& Rotenberg, L. (1996). It's a simple idea, but it's not easy to do: Practical lessons in telementoring. Learning and Leading With Technology 24(2): 53-57.

Harris, J. \& Jones, G. (1999). A descriptive study of telementoring among students, subject matter experts, and teachers: Message flow and function patterns. Journal of Research on Computing in Education 32(1): 36-44.

Haythornthwaite, C., Kazmer, M.M., Robins, J. \& Shoemaker, S. (2000). Community development among distance learners: temporal and technological dimensions. Journal of Computer-Mediated Communication 6(1). Available at http://www. ascusc.org/jcmc/vol6/issuel/haythornthwaite.html (Last accessed 10 July 2003).

Henri, F. (1992). Computer conferencing and content analysis. In A.R. Kaye, ed, Collaborative learning through computer conferencing: The Najaden Papers, pp. 115136. New York: Springer.

Herring, S. (1996). Two variants of an electronic message schema. In S. Herring, ed, Computer-mediated communication: Linguistic, social and cross-cultural perspectives, pp. 81-106. John Benjamins: Amsterdam.

Herring, S. (1999). Interactional coherence in CMC. Journal of Computer-Mediated Communication 4(4). Available at http://www.ascusc.org/jcmc/vol4/issue4/herring.html (Last accessed 10 July 2003).

Howell-Richardson, C. \& Mellar, H. (1996). A methodology for the analysis of patterns of participation within computer-mediated courses. Instructional Science 24: 47-69.

Muller, C. (1997). Potential of industrial "e-mentoring" as a retention strategy for women in science and engineering. Frontiers in Education (FIE) Conference Proceedings. Available at http://www.mentornet.net/Documents/Files/retention.pdf (Last accessed 10 July 2003).

Murfin, B. (1994). An analysis of computer-mediated communication between middle school students and scientist role models: A pilot study. Interpersonal Computing and Technology Journal 2(3): 57-81.

O’Neill, D.K. (1998). Engaging science practice through science practitioners: Design experiments in K-12 telementoring. Doctoral dissertation, Northwestern University. Available at http://www.sfu.ca/ koneill/DKO\%20Diss.pdf (Last accessed 10 July 2003).

O'Neill, D.K. (2001). Enabling constructivist teaching through telementoring. Special Services in the Schools 17(1/2). Binghamton, NY: The Haworth Press.

O’Neill, D.K. \& Gomez, L.M. (1998). Sustaining mentoring relationships on-line. In Proceedings of CSCW 98: ACM Conference on Computer-Supported Cooperative Work, Seattle, November 14-18, 1998. New York: ACM Press, pp. 325-334. Available at http://www.sfu.ca/ koneill/DKO\%20CSCW981.pdf (Last accessed 12 March 2004). 
O’Neill, D.K., Wagner, R. \& Gomez, L.M. (1996). Online mentors: Experimenting in science class. Educational Leadership 54(3): 39-42.

Pena-Shaff, J.B. \& Nicholls, C. (2004). Analyzing student interactions and meaning construction in computer bulletin board discussions. Computers \& Education 42: 243-265.

Rafaeli, S. \& Sudweeks, F. (1997). Networked interactivity. Journal of ComputerMediated Communication 2(4). Available at http://www.ascusc.org/jcmc/vol2/issue4/ rafaeli.sudweeks.html (Last accessed 10 July 2003).

Sonnenwald, D.H., Wildemuth, B. \& Harmon, G. (2001). A research method to investigate information seeking using the concept of information horizons: An example from lower socio-economic students' information seeking behavior. The New Review of Information Behavior Research 2: 65-86.

Sproull, L. \& Kiesler, S. (1993). Computers, networks, and work. In L. Harasim ed, Global networks: Computers and international communication, pp. 106-119. MIT Press: Cambridge.

Tsikalas, K., McMillan-Culp, K., Friedman, W. \& Honey, M. (2000). Portals: A window into telementoring relationships in project-based computational science classes. Paper presented at the Annual Meeting of the American Educational Research Association, New Orleans, LA, April 24-28, 2000. Available at http:// www.ericse.org/CD1/CD/abstracts/ edutech/ED-Tsikalas-2000.htm (Last accessed 10 July 2003).

Tu, C. (2000). Critical examination of factors affecting interaction on CMC. Journal of Network and Computer Applications 23(1): 39-58.

Walther, J. (1992). Interpersonal effects in computer-mediated interaction: A relational perspective. Communication Research 19(1): 52-90.

Walther, J. (1996). Computer-mediated communication: Impersonal, interpersonal, and hyperpersonal interaction. Communication Research 23(1): 3-43.

Walther, J.B. \& Burgoon, J.K. (1992). Relational communication in computer-mediated interaction. Human Communication Research 29: 50-80.

Webster, L., Brassell, E., Sonnenwald, D.H., Wildemuth, B.M., Harmon, G.L., Byrd, G. \& Bollenbacher, W.E. (2000). E-Mentoring Handbook: Lessons Learned from Two Electronic Mentoring Pilot Programs. SILS Technical Report TR-2000-03. Chapel Hill, NC: University of North Carolina, School of Information and Library Science. http://ils.unc.edu/ils/research/reports/TR-2000-03.pdf (Last accessed 10 July 2003).

Wildemuth, B., Sonnenwald, D.H., Bollenbacher, W., Byrd, G. \& Harmon, G. (2001). Mentoring Future Biologists via the Internet: Results from the "Electronic Mentoring for Tomorrow's Scientists" Program. SILS Technical Report TR-2001-07. Chapel Hill, NC: University of North Carolina, School of Information and Library Science. Avaliable at http://ils.unc.edu/ils/research/reports/TR-2001-07.pdf (Last accessed 10 July 2003).

Yacci, M. (2000). Interactivity demystified: A structural definition for distance education and intelligent computer-based instruction. Educational Technology 40(4): $5-16$.

Yates, S. (1996). Oral and written linguistic aspects of computer conferencing. In S. Herring, ed, Computer-mediated communication: Linguistic, social and crosscultural perspectives, pp. 9-46. John Benjamins: Amsterdam.

Young, A.M. \& Perrewé, P.L. (2000). What did you expect? An examination of careerrelated support and social support among mentors and protégés. Journal of Management 26(4): 611-632. 
Zhu, P. (1998). Learning and mentoring: Electronic discussion in a distance learning course. In C.J. Bonk \& K.S. King, eds, Electronic collaborators: learner-centered technologies for literacy, apprenticeship and discourse, pp. 233-259. Erlbaum: Mahwah, NJ. 